\title{
Feasibility of papaya merah delima farming in suburb area of Manado City
}

\author{
Ibrahim Erik Malia ${ }^{1 *}$, Joula O.M. Sondakh ${ }^{1}$, Jantje G. Kindangen ${ }^{1}$, Jeanne Rembang ${ }^{1}$, \\ Jefny $M$. Rawung ${ }^{1}$, and Rita Indrasti ${ }^{2}$ \\ ${ }^{1}$ Assessment Institute for Agricultural Technology DP Sciences, Editorial Department, Jln.Kampus \\ Pertanian Kalasey, Manado, Indonesia \\ ${ }^{2}$ Indonesian Center for Agricultural Technology Assessment and Development, Jln Tentara Pelajar \\ No 10 Bogor, Indonesia
}

\begin{abstract}
A Research has been conducted in Pandu Experimental Garden, Talawaan Bantik Village, North Sulawesi, in 2017-2019. It is located in suburb area of Manado City having high demand of fruits, mainly papaya The objectiveness of the research was to analyze the technical and financial feasibilities of papaya merah delima cultivated in urban area. There were 200 seedlings planted, spacing $2 \mathrm{~m} \times 2.5$. Technically analyzed the parameters such as plant height, stem gird, leaf number, flower number, and fruit setting. It was also compared with farmers method cultivated around the area. Statistically was analyzed by using $t$ test. Financial analysis used R/C Ratio, BEP, and sensitivity. The results shown that the farming is technically and financially feasible. Moreover, the R/C Ratio 2,86 , compared with farmer method 2,21. The benefit gotten for the 200 plants yearly is IDR33,542,000, furthermore, it is an opportunity for the farmer in the area to cultivate papaya merah delima as a main crop. Socially, beside the marketable of the fruit, the city's consumers are interesting for the shape and the small size appearance.
\end{abstract}

\section{Introduction}

Use The suburb area of Manado is specific area for farming. The city has enough space for agriculture purposes, moreover, farmers in this area taking their business according to its specific condition. For distance, they own small area less than 0.5 ha, even some cases, they manage less than 0.1 ha. The dominant commodities planted are horticultural crops, such as sweet corn, tomato, spinach, rambutan, mango and papaya.

Papaya is a main fruit consume daily in Manado like other places in Indonesia. Simple to cultivate and to serve, cheap, interesting texture and delicious are some reasons for its high demands. Papaya is one of fruit having important role in human health due to its nutrient content, such as carbohydrate, protein, beta carotene, iron, calcium, vitamin A, and vitamin $\mathrm{C}[1,2]$. Furthermore, the important nutrient contents are higher than mango, citrus, and bananas $[3,4]$.

\footnotetext{
* Corresponding author: erikmalia08@gmail.com
} 
Therefore, as the popular fresh fruit, papaya attract many attentions in its development. For instance, consumers need advances in taste, shape, textures or any better characters. Recently, in this country, generally people consume papaya $2-5 \mathrm{~kg}$ in weight. Sometimes, it is too big, and a family could not finish it in a day bring about problems such as, the rest become waste, the taste change when it is kept in any package, make them boring, etc. To solve the problems, Indonesian Agency for Agricultural Research and Development (AARD), has released a new variety called merah delima. Advantages of the new variety such as: fruit meat is thick $(>3 \mathrm{~cm})$, orangish red color, very sweet $\left(11-14^{\circ} \mathrm{brix}\right)$, productivity $>70 \mathrm{t} / \mathrm{ha}$, fruit weight $<1.2 \mathrm{~kg}$ [5].

In the last 5 years the farmers in the suburb area of Manado City developing mini papaya like california, calina and merah delima variety planted in small land scale (less than 0.5 ha) However, generally, they cultivated it inefficiently, they use unbalance fertilizer. They use their family labor bringing about unpredicted feasibilities business. Therefore, this research was conducted with objectives to analyze the technical d financial feasibilities of Mini-papaya Merah Delima cultivated in urban area of Manado.

\section{Materials and methods}

The research was conducted in Pandu Experimental Garden and farming around Suburb Area of Manado City in 2017-2019. Mini papaya merah delima was planted in February 2017 , using 0.2 ha (general suburb scale for agriculture), population 200 plants cultivated 2 $\mathrm{m} \times 2.5 \mathrm{~m}$ in spacing. Seedling used was prepared 1 month before planting. Shorting was carried out to get uniform seedling, height $25 \mathrm{~cm}$ and leaf number 5 sheets.

The farmers around the place cultivated papaya merah delima applying the technical assistance by the researchers. Whereas, the farmers were still didn't apply all technology given by researchers due to their several constraints. The recommended technology component adopting by them were superior seed, spacing and weeding. Meanwhile, they only apply urea $(0.5 \mathrm{~kg} /$ plant $)$ to fertilizing their crops.

Furthermore, the parameters measured were:

1. Agronomic Parameters

(1) number of leaves, plant height, stem girth measured in planting time and the first flowering and the next intervals 6 months;

(2) Number of flowers were measured 5 map (month after planting) and the next intervals 4 month follow the flower setting up become fruit;

(3) Number and percentage of fruiting set up was measured 2 months after flower measurement;

(4) Fruit weight, measured when harvesting.

2. Economic Parameters:

(1) Number of fruits harvested, accumulated each 4 months

(2) Price in collecting traders.

(3) Daily price in farmers and traditional market (data series collected since 2016 to 2019)

3. Economic Analysis

(1) Cost Analysis. Cost analysis is a total cost expend in farming, includes fixed and variable cost. Fixed cost is total cost needed in early expenditure, such as land rent, debt interest, taxes, equipment, and building. Moreover, variable cost is total cost needed in production process. Variable cost could be changeable due to its output changeable properties in its production process [6]. In this research, variable cost counted were: the material used once in production process, workers payment, and marketing. The total cost is accumulation of fixed and variable cost, counter as follows formula [7]. 
$\mathrm{TC}=\mathrm{TFC}+\mathrm{TVC}$

where: $\mathrm{TC}=$ Total cost; $\mathrm{TFC}=$ total fixed cost; $\mathrm{TVC}=$ Totalvariable cost

(2) Farming system Revenue. Farming system revenue is production value gained in an agribusiness. Total revenue could be gained by the following formula

$\mathrm{TR}=\mathrm{P} \times \mathrm{TP}$ where: $\mathrm{TR}=$ Total revenue; $\mathrm{P}=$ Price; $\mathrm{TP}=$ total production

(3) Farming system incomes. Farming system income was calculated based on the cost and revenue counted, as follows:

$\pi=\mathrm{TR}-\mathrm{TC}$

Where: $\pi=$ income; TR: Total Revenue; TC: Total cost

(4) Return Cost Ratio Analysis (RC/Ratio)

$\mathrm{R} / \mathrm{C}$ Ratio is a ratio of revenue and production cost formulated as follows,

$\mathrm{R} / \mathrm{C}$ Ratio $=\mathrm{TR} / \mathrm{TC}$

Siregar and Sumaryanto [8] stated that agribusiness of a commodity is concluded feasible if net income at least $20 \%$ of total cost. Therefore, feasibility categories by using $\mathrm{RC} /$ Ratio analysis as follows notification,

(1) $\mathrm{R} / \mathrm{C}$ ratio $>1,2$ : meaning the agribusiness efficient as well as giving a feasible benefit.

(2) $1<\mathrm{R} / \mathrm{C}$ ratio $<1,2$ : meaning the agribusiness is not efficient yet, or it is profitable but the profit not feasible yet.

(3) $\mathrm{R} / \mathrm{C}$ ratio $<1$ : meaning the agribusiness is not feasible.

(4) $\mathrm{R} / \mathrm{C}$ ratio $=1$ : meaning the agribusiness is getting break-even point

(5) Pay back periods. Pay back periods is a period when the cost could be returned [9].

Then, the formula to calculate it is shown as follows:

Pay back periods $=\mathrm{n}+(\mathrm{a}-\mathrm{b}) /(\mathrm{c}-\mathrm{b}) \times 1$ month.

Pay back periods $=($ early investment $) /($ cash flow $) \times 1$ month.

$\mathrm{n}=$ the last month when its cumulative cashflow is still negative

$\mathrm{a}=$ amount of early investment

$\mathrm{b}=$ accumulation of cashflow still negative

$\mathrm{c}=$ cashflow accumulation

(6) Break Even Point. In determaining Break Even Point, 2 factors were analyzed: (a) Break even in production and (b) break even in price. The analysis is used to determine the tolerance of production or product price decreasing where the business is still profitable. The break evens are calculated as follows [10]:

$\mathrm{BEP}$ production $=\mathrm{Cp} / \mathrm{Pc}$

$\mathrm{BEP}$ price $=\mathrm{Cp} / \mathrm{Pt}$

Where: $\mathrm{Pc}=$ product price; $\mathrm{Pt}=$ production; $\mathrm{Cp}=$ production cost (fixed cost and variable cost)

(7) Sensitivity Analysis. An agribusiness income is mostly influent by two main factors, namely, physically total output and price. Moreover, total outputs are generally sensitive in changing due to environment factors, such as climate, pest and disease. Meanwhile, price is sensitive due to availability stock, fruit seasons or its competitiveness to other fruits. Therefore, sensitivity analysis was conducted in two methods: (a) changing the important variables, (b) determining, how deep the changing until the project be infeasible [11].

\section{Results and discussions}

Agribusiness on mini papaya merah delima farming in North Sulawesi is considered relevant, especially for farmers with relatively minimum landholdings. In urban areas, for example Manado, land owned by farmers, including in urban buffer areas, is mostly less 
than 0.5 ha. Farming on this narrow land requires analysis of commodities that have a fairly high economic value. Clusters of high economic value for agricultural commodities generally have a relatively high level of difficulty or obstacles to developing them, for example problems with capital, limited labour and technology. Research in the field of farming systems is an effort to optimize management in managing resource potential, in this case the opportunity for the development of mini papaya merah delima as a commodity that has a fairly high economic value. Farming feasibility testing has been carried out with the results that will be discussed next.

\subsection{Technical feasibilities analysis}

Technical feasibility analysis focused on mini papaya merah delima cultivation activities through measurement of parameters, both vegetative (plant height, number of leaves and stem girth) and generative (number of flowers, number of fruit set, percentage of fruit setting up and fruit weight). Furthermore, analyzed the differences between cultivation practices carried out by researchers and by farmers as comparison (Table 1).

Table 1. Agronomic characters of mini papaya merah delima in Pandu Experimental Garden, 2017-2019

\begin{tabular}{|c|c|c|c|c|c|c|c|}
\hline \multirow[t]{2}{*}{ Parameters } & \multicolumn{7}{|c|}{ Ages (measurement time) } \\
\hline & $\begin{array}{c}\text { Planting } \\
\text { Time }\end{array}$ & 4 map & 10 map & 16 map & 20 map & 24 map & 30 map \\
\hline $\begin{array}{l}\text { Plant } \\
\text { height }(\mathrm{cm})\end{array}$ & \begin{tabular}{|l|}
25.22 \\
\pm 1.1 \\
\end{tabular} & $\begin{array}{l}63.40 \\
\pm 2.0 \\
\end{array}$ & \begin{tabular}{|l|}
111.9 \\
\pm 3.1 \\
\end{tabular} & $\begin{array}{l}165.9 \\
\pm 2.3 \\
\end{array}$ & $\begin{array}{l}205.5 \\
\pm 3.5 \\
\end{array}$ & $\begin{array}{l}233.3 \\
\pm 7.4 \\
\end{array}$ & $\begin{array}{l}248.9 \\
\pm 11.4 \\
\end{array}$ \\
\hline $\begin{array}{l}\text { Stem girth } \\
(\mathrm{cm})\end{array}$ & $\begin{array}{l}3.49 \\
\pm 0.1\end{array}$ & \begin{tabular}{|l|}
18.22 \\
\pm 0.4
\end{tabular} & $\begin{array}{l}49.66 \\
\pm 1.4\end{array}$ & $\begin{array}{l}53.55 \\
\pm 0.7\end{array}$ & $\begin{array}{l}54.38 \\
\pm 1.9\end{array}$ & $\begin{array}{l}54.40 \\
\pm 2.0\end{array}$ & $\begin{array}{l}54.41 \\
\pm 2.01\end{array}$ \\
\hline \multirow[t]{3}{*}{ No. leaves } & $\begin{array}{l}4.90 \\
\pm 0.5 \\
\end{array}$ & $\begin{array}{l}18.15 \\
\pm 1.8\end{array}$ & \begin{tabular}{|l|}
31.80 \\
\pm 3.2 \\
\end{tabular} & \begin{tabular}{|l|}
31.40 \\
\pm 3.7 \\
\end{tabular} & \begin{tabular}{|l|}
27.75 \\
\pm 3.2
\end{tabular} & $\begin{array}{l}24.95 \\
\pm 3.3\end{array}$ & $\begin{array}{l}21.80 \\
\pm 3.0\end{array}$ \\
\hline & \multicolumn{7}{|c|}{ Ages (measurement time) } \\
\hline & 5 map & 9 map & 13 map & 17 map & 21 map & 25 map & 29 map \\
\hline \multirow[t]{3}{*}{ No. Flowers } & $\begin{array}{l}10.65 \\
\pm 3.1\end{array}$ & $\begin{array}{l}14.00 \\
\pm 1.9\end{array}$ & \begin{tabular}{|l}
12.50 \\
\pm 2.9
\end{tabular} & $\begin{array}{l}14.95 \\
\pm 3.5\end{array}$ & $\begin{array}{l}13.10 \\
\pm 3.3\end{array}$ & $\begin{array}{l}15.65 \\
\pm 3.1\end{array}$ & $\begin{array}{l}14.05 \\
\pm 3.1\end{array}$ \\
\hline & \multicolumn{7}{|c|}{ Ages (measurement time) } \\
\hline & 7 map & 11 map & 15 map & 19 map & 23 map & 27 map & 31 map \\
\hline No. Fruit set & \begin{tabular}{|l}
7.00 \\
\pm 2.0
\end{tabular} & $\begin{array}{l}11.50 \\
\pm 2.0\end{array}$ & \begin{tabular}{|l}
9.20 \\
\pm 3.3 \\
\end{tabular} & $\begin{array}{l}11.4 \\
0 \pm 3.7\end{array}$ & $\begin{array}{l}10.00 \\
\pm 3.5 \\
\end{array}$ & $\begin{array}{l}11.85 \\
\pm 3.2\end{array}$ & $\begin{array}{l}10.60 \\
\pm 2.8\end{array}$ \\
\hline $\begin{array}{l}\text { Fruit setting } \\
\text { up (\%) }\end{array}$ & \begin{tabular}{|l|}
68.8 \\
$7 \pm 15.3$
\end{tabular} & $\begin{array}{l}82.29 \\
\pm 11.5\end{array}$ & $\begin{array}{l}71.76 \\
\pm 15.0\end{array}$ & $\begin{array}{l}74.6 \\
\pm 14.9\end{array}$ & $\begin{array}{l}75.3 \\
\pm 14.6\end{array}$ & $\begin{array}{l}74.8 \\
\pm 10.3\end{array}$ & $\begin{array}{l}74.6 \\
\pm 6.1\end{array}$ \\
\hline $\begin{array}{l}\text { Fruit weight } \\
(\mathrm{g})\end{array}$ & & \begin{tabular}{|l|}
853.55 \\
\pm 70.13 \\
\end{tabular} & \begin{tabular}{|l|}
967.40 \\
\pm 56.09 \\
\end{tabular} & \begin{tabular}{|l|}
957.55 \\
\pm 49.47
\end{tabular} & $\begin{array}{l}949.35 \\
\pm 39.72\end{array}$ & $\begin{array}{l}893.55 \\
\pm 65.02\end{array}$ & $\begin{array}{l}766.95 \\
\pm 68.99\end{array}$ \\
\hline
\end{tabular}

Notes: data were calculated primarily; map $=$ month after planting

\subsubsection{Plant height}

Plant height is a parameter that is an important component in papaya cultivation, because it involves nutrient transport capacity, resistance to lying and harvest accessibility and maintenance. The seeds planted with an average height of $25.2 \mathrm{~cm}$, relatively uniform with a standard deviation of 1.1 (Table 1), this is because the seeds were selected with a height category of 24-26 cm. Plant height continues to increase until at the age of 24 map it reaches a height of $233.3 \mathrm{~cm}$ with a relatively small level of diversity, namely $\mathrm{SD}=7.4 \%$. Observation of plant height at the age of 30 months, where the performance of both vegetative and generative has decreased, although the height continues to increase (248.9 $\mathrm{cm})$, the diversity starts to be higher, namely with $\mathrm{SD}=11.4 \%$. 
Plant growth in the treatment carried out by this researcher, compared to that of local farmers, with the same seed source was observed on 20 trees. The results of the study, the comparison of the two treatments analyzed by statistical $t$ test showed variations in several parameters tested (Table 2). The plant height at the age of 24 map in the farmer pattern was $231 \mathrm{~cm}$, while in the research pattern, the plant height was $233.3 \mathrm{~cm}$, and it was not significantly different at the 5\% test level. However, differences were seen in the uniformity of growth, where the SD researcher pattern was quite low, namely 7.39, compared to 20.92 for the farmer pattern. The high diversity in farmer patterns is related to farmer habits in maintenance such as weed control, irrigation, fertilization, etc. Farmers Farming activity, generally does not focus on one commodity, so the time available depends on other business activities or social activities in the village.

\subsubsection{Stem girth}

Random observations of mini papaya merah delima, 20 trees at the time of planting, the age of 4 map was evenly distributed on each sample tree, and at intervals of the following 6 map, showed good uniformity, namely $\mathrm{SD}=0.1 ; 0.4 ; 1,4 ; 0.7 ; 1.9 ; 2.0 ; 2.0$ at planting time, at 4 map, 10 map, 16 map, 20 map, 24 map and 30 map respectively (Table 1). So the standard deviation for the stem girth at each observation is very small.

A comparison test between the researcher and the farmer pattern at the age of 24 map, which is assumed to be the maximum growth of the trunk circumference in one pattern, namely the farmer pattern (Table 2). The average stem girth of the researcher pattern was $54.48 \mathrm{~cm}$, compared to the farmer pattern of $48.83 \mathrm{~cm}$. However, this treatment did not differ statistically. The difference is seen in the level of uniformity, where the pattern of the researchers is quite uniform with $\mathrm{SD}=1.99$; compared to the pattern of farmers with high diversity, the value of $\mathrm{SD}=10.12$.

\subsubsection{Leaves number}

The main function of leaves is to absorb and process sunlight and carbon dioxide through the photosynthetic mechanism, in which $\mathrm{CO} 2$ diffuses from the air through the stomata into the intercellular space $[12,13,14]$,

In general, the character of the number of leaves is quite uniform with a fairly small standard deviation, namely $0.5 ; 1.8 ; 3,2 ; 3,7 ; 3,2 ; 3,3$ and 3,0 , respectively for plants aged $0,4,10,20,24$ and 30 maps. The maximum number of leaves is reached at the age of 16 map and begins to decline at the age of 20 map. This indicates the aging process, although fruit production is still viable. The influence of technology is seen on the productivity of this leaf. This can be seen from the comparison between the researcher pattern ( 27.75 sheet) and the farmer pattern (23.5 sheet), which is statistically different at the test level of $1 \%$.

\subsubsection{Flowers number}

The number of flowers began to be visually observed since the plants began to flower, and data collection was determined when all plants had flowered regardless of those that had become fruit. At the age of 5 map, the average number of flowers was 10.65 / plant with a standard deviation of 3.1. The next observations, the number of flower increase, then, it is relatively stable from the age 9, 13, 17, 21, 25 till 29 map (Table 1). It is also important that the value standard of deviation is low in all measurement time, less than 3.5 , meaning uniformity. 


\subsubsection{Fruit set number}

The number of fruits set up is a representation of the agronomic performance of plants in the generative phase (Table 2). The number of fruits set up is 2 months after observing the fruit to ensure that they will not fall (except for mechanical factors). At the age of 7 maps, the average number of fruits set up was 7 with a percentage of $68.8 \%$. Furthermore, at 4 map intervals it continued to increase and peaked at the age of 27 map, namely 10 pieces with a percentage of $74.5 \%$. The uniformity of the number of fruits set up is very good with $\mathrm{SD}= \pm 2.0- \pm 3.5$.

Fruit weight is a very important parameter in farming, because in product marketing, fruit weight is a commonly used as main measurement. The fruit weight of this study at the first harvest an average of $853.55 \mathrm{~g} /$ nut, increasing in the next 4 months $967.40 \mathrm{~g} /$ nut. After the peak, fruit weight decreased at the age of 27 map.

Table 2. Differentiation of researches and farmers methods on leaf number, stem girth, and plant height of mini papaya merah delima in Suburb of Manado

\begin{tabular}{|c|c|c|c|c|c|c|}
\hline No & \multicolumn{2}{|c|}{ No. Leaves } & \multicolumn{2}{c|}{ Stem girth (cm) } & \multicolumn{2}{c|}{ Plant height (cm) } \\
\hline & Researcher & Farmer & Researcher & Farmer & Researcher & Farmer \\
\hline 1 & 28.0 & 28.0 & 54.2 & 41.6 & 235.2 & 221.2 \\
\hline 2 & 30.0 & 29.0 & 54.8 & 58.0 & 238.1 & 265.2 \\
\hline 3 & 30.0 & 27.0 & 55.0 & 56.2 & 238.4 & 247.3 \\
\hline 4 & 22.0 & 12.0 & 53.1 & 35.6 & 239.1 & 195.2 \\
\hline 5 & 29.0 & 28.0 & 54.0 & 60.1 & 232.6 & 259.0 \\
\hline 6 & 30.0 & 25.0 & 54.4 & 58.6 & 235.4 & 245.0 \\
\hline 7 & 28.0 & 26.0 & 52.8 & 61.3 & 229.3 & 267.3 \\
\hline 8 & 31.0 & 31.0 & 52.5 & 63.4 & 228.7 & 247.7 \\
\hline 9 & 19.0 & 29.0 & 52.1 & 40.8 & 223.9 & 227.5 \\
\hline 10 & 22.0 & 24.0 & 54.3 & 37.8 & 219.6 & 200.6 \\
\hline 11 & 24.0 & 14.0 & 55.7 & 36.8 & 225.7 & 208.2 \\
\hline 12 & 26.0 & 18.0 & 54.0 & 36.9 & 214.8 & 216.6 \\
\hline 13 & 21.0 & 27.0 & 53.1 & 58.2 & 241.2 & 240.9 \\
\hline 14 & 35.0 & 17.0 & 53.0 & 50.2 & 239.1 & 235.0 \\
\hline 15 & 22.0 & 13.0 & 56.3 & 41.2 & 236.3 & 226.0 \\
\hline 16 & 33.0 & 19.0 & 54.0 & 57.0 & 240.0 & 237.0 \\
\hline 17 & 33.0 & 25.0 & 53.1 & 53.0 & 238.8 & 228.8 \\
\hline 18 & 31.0 & 24.0 & 53.1 & 41.2 & 239.4 & 225.7 \\
\hline 19 & 31.0 & 26.0 & 58.3 & 54.0 & 237.2 & 230.1 \\
\hline 20 & 30.0 & 28.0 & 60.2 & 34.7 & 232.5 & 198.5 \\
\hline Ave. & $27.75 \mathrm{~ns}$ & 23.50 & 54.40 & 48.83 & 233.3 & 231.1 \\
\hline T-test & $2.09<.11>2.86 \mathrm{ss}$ & $2.09>1.70<2.86 \mathrm{~ns}$ & $2.09>1,28<2.86 \mathrm{~ns}$ \\
\hline SD & 4.59 & 5.83 & 1.99 & 10.12 & 7.39 & 20.92 \\
\hline
\end{tabular}

In comparing between researcher and farmer methods, in fact, that differentiation of the two methods is significant in all parameters (Table 3). Based on the T test analysis, in parameters of flower numbers, fruit numbers, fruiting set up and fresh fruit weight, the superiority of researcher's methods were very significant hinger results than the farmer's methods. That probably related to the external factors, such as fertilizer and maintaining cultivation. When researchers used the recommended fertilizer, the farmers used it accorded to their custom. Generally, they used mostly Urea only or NPK in unbalance portion.

The role of fertilizer on flowering and fruiting set up may be supported by several researches. According to Kusumayati [15], that the flowering and fruiting is much influenced by PGR Gibberellin. The high content of carbohydrate in bud is needed to provide sufficient initial energy in flower induction and developing of meristem area and 
flower organs [16,17]. $\mathrm{C} / \mathrm{N}$ ratio increase in early flower induction [18]. The increasing of $\mathrm{C} / \mathrm{N}$ ratio in plat bud is relation to increasing in carbohydrate availability. Furthermore, the flower and fruit developing also influence by the ability of a plant to absorb nutrient and using it effectively [19].

Table 3. Differentiation of researches and farmers methods on flower number, fruit set up and percentage of fruit set up of Merah Delima Papaya in Suburb of Manado

\begin{tabular}{|c|c|c|c|c|c|c|c|c|}
\hline \multirow[t]{2}{*}{ No } & \multicolumn{2}{|c|}{ Flower Number } & \multicolumn{2}{|c|}{ Fruit Set Up } & \multicolumn{2}{|c|}{$\begin{array}{l}\text { Percentage of } \\
\text { Fruit Set Up (\%) }\end{array}$} & \multicolumn{2}{|c|}{$\begin{array}{l}\text { Fruit weight } \\
\text { (g) }\end{array}$} \\
\hline & $\operatorname{Res}$ & Farmer & $\operatorname{Res}$ & Farmer & Res & Farmer & Res & Farmer \\
\hline 1 & 15 & 12 & 11 & 5 & 73,33 & 41,67 & 923 & 707 \\
\hline 2 & 14 & 17 & 9 & 7 & 64,29 & 41,18 & 890 & 812 \\
\hline 3 & 18 & 14 & 13 & 4 & 72,22 & 28,57 & 981 & 742 \\
\hline 4 & 19 & 16 & 15 & 10 & 78,95 & 62,50 & 934 & 724 \\
\hline 5 & 21 & 14 & 15 & 5 & 71,43 & 35,71 & 944 & 900 \\
\hline 6 & 14 & 16 & 12 & 10 & 85,71 & 62,50 & 912 & 712 \\
\hline 7 & 11 & 9 & 5 & 6 & 45,45 & 66,67 & 953 & 569 \\
\hline 8 & 12 & 9 & 8 & 4 & 66,67 & 44,44 & 923 & 800 \\
\hline 9 & 14 & 17 & 8 & 12 & 57,14 & 70,59 & 963 & 598 \\
\hline 10 & 17 & 14 & 13 & 8 & 76,47 & 57,14 & 988 & 751 \\
\hline 11 & 15 & 16 & 9 & 13 & 60,00 & 81,25 & 956 & 825 \\
\hline 12 & 10 & 13 & 7 & 6 & 70,00 & 46,15 & 1023 & 723 \\
\hline 13 & 17 & 8 & 15 & 7 & 88,24 & 87,50 & 1008 & 781 \\
\hline 14 & 14 & 8 & 13 & 5 & 92,86 & 62,50 & 893 & 698 \\
\hline 15 & 19 & 13 & 13 & 7 & 68,42 & 53,85 & 963 & 745 \\
\hline 16 & 17 & 8 & 12 & 6 & 70,59 & 75,00 & 940 & 753 \\
\hline 17 & 13 & 12 & 8 & 5 & 61,54 & 41,67 & 1000 & 728 \\
\hline 18 & 17 & 7 & 12 & 4 & 70,59 & 57,14 & 924 & 812 \\
\hline 19 & 12 & 8 & 8 & 5 & 66,67 & 62,50 & 983 & 747 \\
\hline 20 & 13 & 8 & 8 & 6 & 61,54 & 75,00 & 886 & 734 \\
\hline Ave. & 15,10 & 11,95 & 10,70 & 6,75 & 70,10 & 57,68 & 949,35 & 743,05 \\
\hline $\begin{array}{c}\mathrm{T}- \\
\text { test }\end{array}$ & \multicolumn{2}{|c|}{$\begin{array}{c}2.09<3.46>2.86 \\
\text { Ss }\end{array}$} & \multicolumn{2}{|c|}{$2.09<4.46>2.86 \mathrm{ss}$} & \multicolumn{2}{|c|}{$2,09<2.92>2.86 \mathrm{ss}$} & \multicolumn{2}{|c|}{$2,09<10,07>2.86 \mathrm{ss}$} \\
\hline SD & 2.94 & 3.52 & 2.99 & 2.61 & 11.03 & 15.93 & 39.72 & 73.42 \\
\hline
\end{tabular}

The weakness of farmer in applying efficient fertilizer commonly in selecting appropriate balance of macro nutrient content. That probably cause less results in flower and fruit production than the researcher who use recommended fertilizer technology. The nutrients and compound usually lack in farmer's dosage, such as Phosphorous (P), potassium $(\mathrm{K})$ and organic matter. Phosphorous is very needed by plant in developing its flowering, roots and shoots growing [20]. Then, potassium nutrient is most important in protecting flower fall, meaning increase the fruit setting up [21]. Meanwhile, the organic matter supplying into soil will perform decomposition proses producing decomposed organic matter very important because having colloid hydrophilic properties be able to agglomerate and shape gel producing porous soil [22]. Decomposed organic matter have high water holding capacity needed to provide available water for plant [23].

\subsection{Financial analysis}

\subsubsection{Cost Analysis}

The costs required for the agribusiness of mini papaya merah delima small scale 200 plants (0.2 ha) in Pandu experimental Garden, North Minahasa Regency. This is done to create 
an alternative simulation for the development of mini papaya merah delima agribusiness that is identical to the scale at the farmer level which is quite a lot in the ring area or suburb area of Manado City. Therefore, the cost analysis is divided into two aspect, namely fixed costs and variable costs.

\subsubsection{Fixed Costs}

Calculation of fixed costs for the component of land purchase or rental is ignored, because it is considered to be owned by the farmer. Therefore, the fixed costs for this farm are relatively small, which is only IDR 1,720,000, which includes the purchase of a hoe, knife, shovel and electric sprayer.

\subsubsection{Variable cost}

Variable costs include purchases of materials and labor costs. Materials purchased are consumables, so they are not included in fixed costs. These ingredients are pomegranate red papaya seeds ordered from farmers under the supervision of researchers so that the quality is in accordance with the expected criteria, as well as prospective for the farmer concerned, which allows him to increase the volume of his business as a seller of the papaya seeds in his area. The number of seedlings purchased was 220 tillers, $10 \%$ more for the reserve for embroidery, at a price of Rp. 5,000 / tiller, the total cost of seedlings was IDR 1,100,000. Other materials purchased are NPK fertilizer (15-15-15) of 5 sacks (@20 kg) x IDR 240,000 (non-subsidized) $=$ IDR 1,200,000. The manure used is manure for laying hens, as many as 40 sacks of IDR $12,000 /$ sack $=$ IDR 480,000. The price of this manure is more expensive than the farmer's average sales (only Rp. 8,000/ sack), because it is specially ordered and given technical guidance to produce ready-to-use manure that is well decomposed. In general, manure sold by farmers/breeders is still not well decomposed, so there is an increased risk of pest attack and disturbance of organic acids on plants. The pesticides used are insecticides and fungicides that are applied according to general recommendations, which is used during the method. others have been ineffective such as sanitation and mechanics and the attack has exceeded the economic threshold of about $5 \%$. The total pesticide cost is IDR 1,200,000. The total variable cost is Rp. 16,335,000.

\subsubsection{Total Cost Analysis}

The total cost in mini papaya merah delima agribusiness of small scale in suburb area of Manado City is obtained from the total costs in one period of 33 map which are the sum of these two costs [7]. The total cost required in this agribusiness practice is IDR 18,055,000 (Table 4). 
Table 4. Financial analysis of mini papaya merah delima in small scale suburbs area of Manado City, in IDR

\begin{tabular}{|l|c|r|r|r|}
\hline \multicolumn{1}{|c|}{ Subjects } & \multicolumn{1}{c|}{ Volume } & \multicolumn{1}{c|}{ Unit } & \multicolumn{1}{c|}{ Unit Cost } & \multicolumn{1}{c|}{ Amount } \\
\hline A. Fixed Cost & & & & \\
\hline Hoe & 2 & piece & 80000 & 160.000 \\
\hline Knife & 2 & piece & 150000 & 300.000 \\
\hline Shovel & 2 & piece & 80000 & 160.000 \\
\hline Electric sprayer & 1 & piece & 1100000 & 1.100 .000 \\
\hline B. Variable Cost & & & & \\
\hline Labour & & & & \\
\hline Tillage & 32 & Man & 100000 & 3.200 .000 \\
\hline Planting & 16 & Man & 100000 & 1.600 .000 \\
\hline $\begin{array}{l}\text { Fertilization, irrigation, pest } \\
\text { spraying, and other maintenance }\end{array}$ & 36 & Man & 100000 & 3.600 .000 \\
\hline Harvesting & 12600 & Nut & 300 & 3.780 .000 \\
\hline Materials & & & & \\
\hline Seedling & 220 & Plant & 5000 & 1.100 .000 \\
\hline $\begin{array}{l}\text { Compound fertilizer } \\
\text { NPK (@20 kg) }\end{array}$ & 5 & Sack & 240000 & 1.200 .000 \\
\hline Manure & 40 & Sack & 12000 & 480.000 \\
\hline Pesticides & 3 & package & 400000 & 1.200 .000 \\
\hline Mask & 50 & Sheet & 1500 & 75.000 \\
\hline Pail & 4 & Piece & 25000 & 100.000 \\
\hline C. Total Cost & & & & 18.055 .000 \\
\hline Revenue & 12600 & Nut & 4095 & $\mathbf{5 1 . 5 9 7 . 0 0 0}$ \\
\hline Income & & & & $\mathbf{3 3 . 5 4 2 . 0 0 0}$ \\
\hline R/C RATIO & & & & $\mathbf{2 , 8 6}$ \\
\hline & & & & \\
\hline
\end{tabular}

\subsubsection{Revenue, Income and Return Cost Ratio Analysis (RC/Ratio)}

Farming system revenue is production value gained in an agribusiness. Total revenue is influenced much by to factors, namely production and price. The total production gained in this directed scale agribusiness is 12,600 nuts. In Manado city, selling transaction is generally by nuts number instead of weight as product unit. Meanwhile, the price as shown in Fig.1 and Fig 2, is fluctuated. The fluctuation is significant in peak season where the price fall down to less than IDR 2,000/nut. The peak season in December to the January when abundant production of mostly fruit includes papaya. It is also related to annual climate routine, especially heavy rainy season impact.

Moreover, in this analysis, price using is an average of two years monthly price of mini papaya in farmer level, where mostly bought by collecting trader. The revenue gained was IDR 51,597,000. The income, is deviation of revenue and the cost as net gaining in any farming business. In this case, the income is IDR 33,542,000. As their custom, the farmer in the suburb area, farming in small scale is not only their job. They also do any other job, like parttime work as fisherman, carpenter, collecting trader, public transportation driver, labour, and any other services needed in the city. Furthermore, they may gain the revenue as net income due to the family labour is still available for the small scale of farming system. 


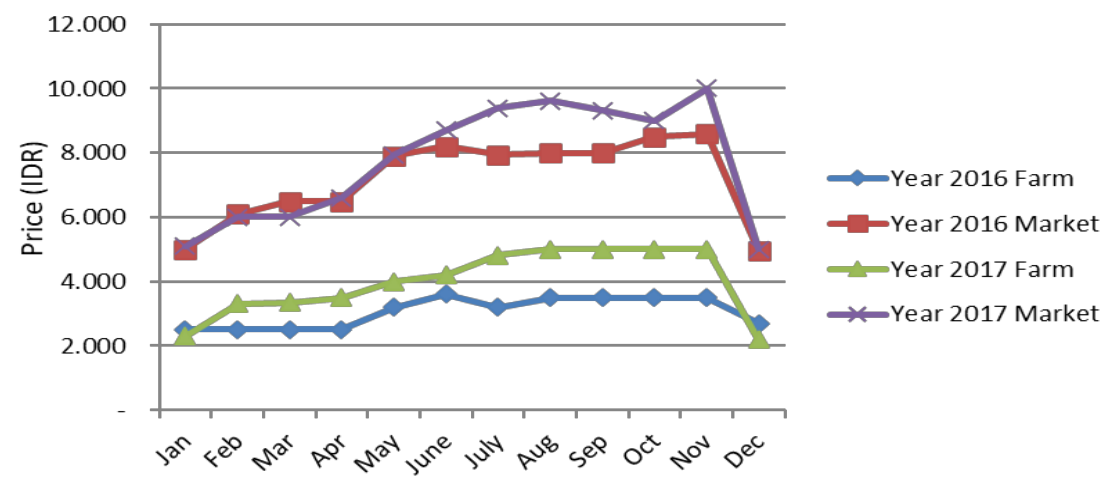

Fig. 1. Price of mini pepaya merah delima in Manado City, 2016-2017

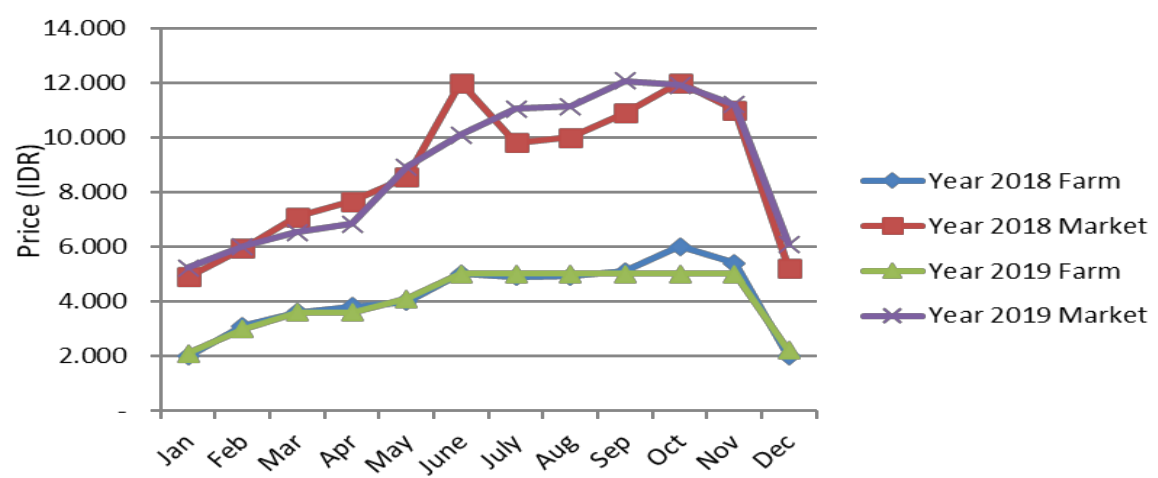

Fig. 2. Price of mini pepaya merah delima in Manado City, 2018-2019

Feasibility of the agribusiness of small scale of mini papaya merah delima in suburbs area of Manado City, firstly determined by returned cost ratio analysis, $\mathrm{R} / \mathrm{C}$ ratio. In this research was gotten $\mathrm{R} / \mathrm{C}$ Ratio 2.86 , above 1.2 meaning the agribusiness efficient as well as giving a feasible benefit [8]. The feasibility of farming system of mini papaya is proved by some researcher in other place in Indonesia. In Bojonegoro, East Java, Rahmawati [24] was resulting the feasibility of mini papaya california. California variety is a mini papaya similar to merah delima, but merah delima is sweeter. Feasibility of mini papaya in Bogor, East Java Province [25], in Balikpapan, East Kalimantan [26], in Bali [27].

\subsubsection{Pay-back period}

Payback period is a period of time to find out when in what month or year (when) all California papaya farming costs can be returned [9]. All papaya farmers sell their production gradually or periodically. And to find out when the papaya farming production costs can return by using the pay-back period. In calculating the payback periods is needed cash flow of the business, as shown in Table 5, as follows

Table 5. Cashflow of agribusiness mini papaya merah delima in subarbs area Manado City

\begin{tabular}{|c|c|c|c|c|c|c|c|c|}
\hline \multirow{2}{*}{ Subjects } & \multicolumn{8}{|c|}{ 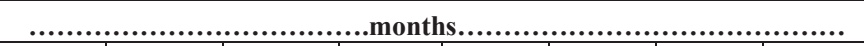 } \\
\hline & 6 & 9 & 12 & 15 & 18 & 21 & 24 & 27 \\
\hline Net cash flow & -16335 & 620 & 3550 & 9261 & 16811 & 24824 & 29597 & 36020 \\
\hline Cumulative net cash flow & & -15715 & -12165 & -2904 & 13907 & 38731 & 68328 & 104348 \\
\hline
\end{tabular}


Based on the cash flow analysis, it can be shown that until the age of 15 map, the cashflow of the red pomegranate farming is still negative and at the age of 16 bst the cash flow is positive. The result of calculating the Payback Period for this ruby farm is 15.7 months. This means that the break-even point occurs at the age of 15.7 bst or 15 months and 21 days. According to Dwijatenaya [28], the faster the return on investment in papaya farming, the more feasible it is to cultivate it.

\subsubsection{Break Even Point}

The results of the analysis of the break-even point in production are 4409 nuts, which means that the mini papaya merah delima farming in the suburbs area of Manado City will not get loss if the decline in production does not reach 4409 nuts/0.2ha. Moreover, the results of the analysis of the break-even in price were IDR1433/nut, indicating that this business will not get loss if the price reduction does not exceed Rp.1433/nut

\subsubsection{Sensitivity Analysis}

Based on the above feasibility analysis, it is known that small scale pomegranate papaya (0.2 ha) relevant to the urban area of Manado City is feasible. However, this farm is sensitive to the changes that exist so it is necessary to do a sensitivity analysis.

Table 6. Sensitivity Analysis of agribusiness on mini papaya merah delima in suburb area of Manado City.

\begin{tabular}{|c|c|c|c|c|}
\hline \multirow{2}{*}{$\begin{array}{l}\text { Output } \\
\text { Price (Rp) }\end{array}$} & \multicolumn{4}{|c|}{ Productivity } \\
\cline { 2 - 5 } & $\mathbf{0 \%}$ & $\mathbf{5 \%}$ & $\mathbf{1 5 \%}$ & $\mathbf{2 5 \%}$ \\
\hline \multirow{2}{*}{$0 \%$} & 33.542 .000 & 31.864 .900 & 28.510 .700 & 25.156 .500 \\
& RCR: 2,86 & RCR: 1,76 & RCR: 1,58 & RCR: 1,39 \\
\hline \multirow{2}{*}{$-10 \%$} & 30.187 .800 & 28.510 .700 & 25.156 .500 & 21.802 .300 \\
& RCR: 1,67 & RCR: 1,58 & RCR: 1.39 & RCR: 1,39 \\
\hline \multirow{2}{*}{$-20 \%$} & 26.833 .600 & 25.156 .500 & 21.802 .300 & 18.448 .100 \\
& RCR: 1,49 & RCR: 1,39 & RCR: 1,21 & RCR: 1,02 \\
\hline \multirow{2}{*}{$-30 \%$} & 23.479 .400 & 21.802 .300 & 18.448 .100 & 15.093 .900 \\
& RCR: 1,30 & RCR: 1,21 & RCR: 1,02 & RCR: 0,84 \\
\hline \multirow{2}{*}{$-40 \%$} & 20.125 .200 & 18.448 .100 & 15.093 .900 & - \\
\hline \multirow{2}{*}{$-50 \%$} & RCR: 1,11 & RCR: 1,02 & RCR: 0,84 & \\
& 16.771 .000 & 15.093 .900 & & \\
\hline
\end{tabular}

In this study, a sensitivity analysis was carried out (Table 6) towards a reduction in the price level of pomegranate papaya by $0 \%$ and gradually simulated at a reduction rate of $10 \%, 20 \%, 30 \%, 40 \%$ and $50 \%$ where the RC Ratio was less than 1 . This category is also based on inflation sensitivity, price fluctuation and overproduction. Potential losses in farming can also occur due to decreased production, which can be caused by factors such as climate anomalies, pest and disease attacks or theft. However, the potential for a decrease in productivity is not as big as price fluctuations, so that the sensitivity of the decline is $0 \%$, $10 \%$ and $15 \%$, with the assumption that if it is managed properly, it is assumed that there will be no more decline in productivity exceeding $15 \%$.

It can be seen in Table 5 that changes in output prices and productivity of papaya merah delima will cause significant changes to the $\mathrm{R} / \mathrm{C}$ Ratio value. Feasibility based on $\mathrm{R} / \mathrm{C}$ Ratio analysis, will be obtained until a certain level of price reduction and productivity. Based on the rule, that it is worth and efficient at B/C Ratio 1.2 and above, these results indicate that the ruby-red farming is feasible and efficient even though it has decreased: (a) 
the price is $30 \%$ without price reduction, (b) the price $20 \%$ with a decline in production as high as $15 \%$; (c) $10 \%$ price with a decline in production of no more than $25 \%$. Furthermore, at a price reduction of $40 \%$ with a decrease in production of more than $5 \%$, there is still a break-even point, farming does not lose money but is not efficient because the $\mathrm{B} / \mathrm{C}$ ratio is more than 1 , but less than $1.2[8]$.

\section{Conclusion}

Agribusiness in suburbs area of Manado City, is an opportunity by Farming system of mini papaya merah delima showing feasibility on both technical and financial aspects. Technical analysis on both vegetative and generative aspects were indicated the feasibility to develop as family business. Whereas, the technology role is needed to increase the importance of the farming system, since the insisting farmers farming system practice is not effective and efficient yet. There were significant different on several parameters measured between the researcher and farmer methods due to the luck technology applied by the farmers yet.

Financial feasibilities are shown such in, R/C Ratio 2.86, payback periods in 15.7 map, break-even point in production 4409 nuts, break-even point in price IDR1433/nut. The sensitivity is still feasible until accumulation of production and price $45 \%$.

\section{References}

1. Idayu, IM, Asyikin, N. Md, S, Liza, Khaerudin, N, Drying characteristic of papaya (Carica papaya L.) during microwave vacuum treatment', in Proceedings of the World Engineering Congress, 5-9 August 2007, Penang, Malaysia (2007)

2. Workneh, TS, Azene, M, Tesfay, S.Z., Afr. J. Biotech. 11, 85, 15098-15110 (2012)

3. Aravind, G, Debjit Bhowmik, Duraivel, S, Harish, G., J. Med. Plants Stud. 1, 1, 7-15 (2013).

4. USDA, Nutrient values and weights are for edible portion USDA National Nutrient Database for Standard Reference Release, Basic Report 09226 Papayas raw (2013)

5. Budianti, T., Sunyoto, Varietas unggul baru papaya merah delima si merah yang manis, (Sinar Tani, Jakarta, 2011)

6. Soekartawi, Prinsip Dasar Ekonomi Pertanian Teori dan Aplikasi (PT. Raja Grafindo Persada, Jakarta, 2002)

7. Soeharjo, A., Patong, D., Sendi-Sendi Pokok Ilmu Usahatani (Fakultas Pertanian. IPB, Bogor, 1973)

8. Siregar, M., Sumaryanto, J. Agroekonomi 21, 1 (2003)

9. Arifin, J., Perencanaan Bisnis (PT Elex Media Komputindo, Jakarta, 2008)

10. Rahmanto, B., M.O. Adnyana, Potensi SUTPA dalam meningkatkan kemampuan daya saing komoditas pangan di Jawa Tengah, in Proceedings National Seminar The Dynamics of the Rural Economy and Increasing Competitiveness of the Agricultural Sector [in Bahasa], 5-6 Agustust 1997, Bogor, Indonesia (1997)

11. Kadariah., Evaluasi Proyek (FEUI, Jakarta, 1986)

12. Smith, W.K., Vogelmann, T.C., DeLucia, E.H., Bell, D.T., K.A. Shepherd, BioScience 47, 11, 785-793 (1997)

13. Taiz, L., E. Zieger, Plant physiology (Sinauer Associates Inc. Publishers. Sunderland, Massachusetts, USA, 1998)

14. Terashima, I., Hanba, Y.T., Tholen, D., U. Niinemets, Plant Physiol. 155, 108-116 (2011)

15. Kusumayati, N., Nurlaelih, E. E., L.Setyobudi, J. Produksi Tanam. 3, 8, 683-688 (2015) 
16. Hempel, F.D., D.R Welch, L.J. Feldman, J. Trends Plant Sci. 5, 17-21 (2000)

17. Widaryanto, E., C. Udayana, M. Baskara, R. Umiarti, Studi pertumbuhan dan pembungaan tiga jenis Impatiens wallerana pada berbagai tingkat naungan, in Proceedings of the National Seminar PERHORTI, 23-24 November 2011, Balitsa, Lembang, Indonesia (2005)

18. Upreti, K.K., Y.T.N. Reddy, S.R.S. Prasad, G.V. Bindu, H.L. Jayaram, S., Scientia Horticulturae 150, 414-418 (2013)

19. Gardner, V.R, F.C. Bradford, H.D. Hooker, Jr., The Fundamental of Fruit Production. New York (McGraw-Hill Book Company Inc., 1939)

20. Meylia, R.D, Koesriharti, J. Produksi Tanam. 6, 8, (2018)

21. Erwiyono, R., A. A. Sucahyo, Suyono, S. Winarso, Pelita Perkeb. 22, 1, 13-24 (2006)

22. Intara, Y. I., Asep, S., Erizal, Namaken, S., Bintoro, D., Ilmu Pertan. Indonesia 16, 2, 130-135 (2011)

23. Nurwanto, A., Soedradjad, R., N.Sulistyaningsih, Agritrop 15, 2, 181- 193 (2017)

24. Rahmawati, L.A., ORYZA 1, 2 (2016)

25. Chaerningrum, R., Analisis Usahatani Pepaya California (Kasus: Desa Cikopo Mayak, Kecamatan Jasinga, Kabupaten Bogor, Provinsi Jawa Barat) [Sripsi] (IPB, 2010)

26. Susanti, T., Ratini, R., Mariyah, J. AGRIFOR 13, 1 (2014)

27. Widyaningsih, M.A., K. Kariada, Kajian Usahatani Pengembangan Varietas Unggul Baru (VUB) Pepaya California di Desa Kerta Kecamatan Payangan Kabupaten Gianyar in Proceeding National Seminar Agricultural Technology Innovation 20 July 2016, Banjarbaru, Indonesia (2016)

28. Dwijatenaya, I.B.M.A., Nugroho, A. E., Iskandar, SIRAA’AH 44, 2, 236-244 (2019) 